ISSN 0819-2642

ISBN 0734025890

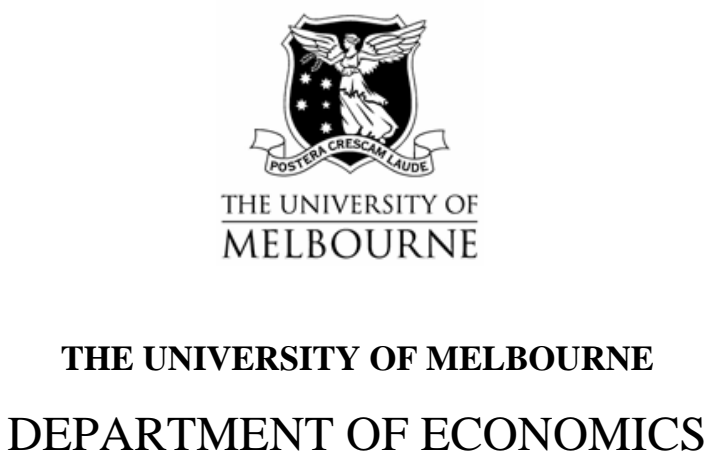

RESEARCH PAPER NUMBER 933

MARCH 2005

\title{
CARBON DIOXIDE EMISSIONS \\ REDUCTIONS IN NEW ZEALAND: \\ A MINIMUM DISRUPTION APPROACH
}

by

John Creedy

$\&$

Catherine Sleeman

Department of Economics

The University of Melbourne

Melbourne Victoria 3010

Australia. 


\title{
Carbon Dioxide Emissions Reductions in New Zealand: A Minimum Disruption Approach
}

\author{
John Creedy and Catherine Sleeman ${ }^{2}$ \\ The University of Melbourne and the \\ Reserve Bank of New Zealand
}

\begin{abstract}
Reductions in carbon dioxide emissions can come from (among other things) changes to the structure of final demands, changes in the use of fossil fuels by industry, and changes to the structure of inter-industry transactions. This paper examines the nature of the least disruptive changes, that is the minimum changes to these three components which are consistent with specified overall reductions in carbon dioxide emissions in New Zealand. In examining the minimum changes needed, constraints are imposed on the corresponding changes in GDP growth and aggregate employment.
\end{abstract}

$\begin{aligned} & \text { JEL CLASSIFICATION N57 } \text { D4 } \\ & \text { Q5 } \\ & \text { L7 }\end{aligned}$

K E Y W O R D S Carbon Dioxide; Minimum Disruption; Carbon Intensities; New Zealand

\footnotetext{
${ }^{1}$ The first draft of this paper was written at the New Zealand Treasury. The views, opinions, findings, and conclusions or recommendations expressed in this Working Paper are strictly those of the authors. They do not necessarily reflect the views of the New Zealand Treasury or those of the Reserve Bank of New Zealand. We should like to thank Statistics New Zealand, in particular Jeremy Webb, for making available its monetary and physical estimates of fuel use by industry. This information is from the Statistics New Zealand Energy Flow Account report that was published in March 2004. We are also grateful to Iris Claus for help with the InputOutput data, and a referee for helpful comments.

${ }^{2}$ Corresponding author: jcreedy@unimelb.edu.au
} 


\section{Carbon Dioxide Emissions Reductions in New Zealand: A Minimum Disruption Approach}

\section{Introduction}

A reduction in carbon dioxide emissions arising from the production of goods and services can come from three main sources: changes to the structure of final demands; changes to fuel mix and efficiency in production, and changes to the structure of inter-industry trading. The aim of this paper is to examine the nature of the least disruptive changes in the New Zealand economy that are necessary to achieve a target annual rate of reduction in emissions. The extent of the disruption to any variable, say the output of an industry, is measured by its proportional change. The paper concentrates on changes in final consumer demands and changes in the quantities and mixture of fossil fuels used by industries. A situation in which the target reduction in emissions is achieved by reducing all final demands would imply an increase in aggregate unemployment and a negative growth rate of GDP. For this reason, and in the case of final demand changes, the effects of imposing constraints on GDP and employment growth are examined. These constraints imply that the final demands of some industries need to increase, while other industries decline. These changes are examined using constrained minimisation techniques within an input-output framework, following the methods developed by Proops et al (1993). ${ }^{3}$

The constrained minimisation method does not consider a specified means of reducing emissions, such as a carbon tax. ${ }^{4}$ It is therefore not directly concerned with determining the economic costs associated with curbing carbon dioxide emissions. Instead the method attempts to find the minimum set of structural changes required in different industries of the economy that would achieve a target level of emissions reduction whilst maintaining predetermined levels of variables such as GDP growth and employment. In doing so, the method can determine the severity of the required changes.

Subsection 2.1 presents the input-output approach to modelling carbon dioxide emissions, while subsection 2.2 describes the method of allowing for the constrained minimisation of disruptions. The minimum disruption approach is applied to New Zealand in sections 3 and 4 . Section 3 describes the sources from which the data were gathered and the processes used to form the expressions derived in section 2. Section 4 analyses the minimum disruption results for final demands and fuel use. Conclusions are provided in section 5 .

\footnotetext{
${ }^{3}$ For an application to Australia, see Cornwell and Creedy (1997).

${ }^{4}$ For an analysis of the implications of a carbon tax for household demands and welfare in New Zealand, see Creedy and Sleeman (2004).
} 
This section presents the framework of analysis used to compute minimum disruption changes. Subsection 2.1 derives an expression for total carbon dioxide emissions, using an input-output approach. Subsection 2.2 derives the minimum disruption changes to final demands necessary to achieve a required rate of reduction in total carbon dioxide emissions, subject to growth and employment constraints. Finally, subsection 2.3 examines the changes in the fuel-use coefficients required to achieve a target carbon dioxide emissions reduction.

\subsection{Total Carbon Dioxide Emissions}

Consider increasing the final consumption of a good by $\$ 1$. The problem is to evaluate how much carbon dioxide this would involve. This increase in final demand involves a larger increase in the gross, or total output, of the good - as well as requiring increases in the outputs of other goods. This is because intermediate goods, including the particular good of interest, are needed in the production process. The extent to which there is an increase in carbon dioxide emissions depends also on the intermediate requirements of all goods which are themselves intermediate requirements for the particular good. Indeed, the sequence of intermediate requirements continues until it 'works itself out', that is the additional amounts needed become negligible. This is in fact a standard multiplier process and can be set out formally as follows.

An industry's gross output derives from both final demand and intermediate output, which serves as input to other industries. Let $x_{i j}$ denote the value of output flowing from industry $i$ to industry $j$, and let $y_{i}$ denote the value of final demand by consumers for the output of industry $i$. The value of an industry's gross output, $x_{i}$, may therefore be expressed as the sum of intermediate and final demands:

$$
x_{i}=\sum_{j} x_{i j}+y_{i}
$$

The direct requirement co-efficient, $a_{i j}$, measures the value of output from industry $i$ directly required to produce $\$ 1$ worth of output in industry $j$. Hence:

$$
a_{i j}=\frac{x_{i j}}{x_{i}}
$$

Using (2) to write $x_{i j}=a_{i j} x_{i}$ and substituting the resulting expression into equation (1) gives gross output as:

$$
x_{i}=\sum_{j} a_{i j} x_{i}+y_{i}
$$

Let $x$ and $y$ denote the n-element vectors of $x_{i}$ and $y_{i}$ respectively. Further, let $A$ denote the $(n \times n)$ matrix of the direct requirement coefficients, $a_{i j}$. These definitions enable the system of $n$ equations described in equation (3) to be expressed in matrix notation as:

$$
x=A x+y
$$

Continuous substitution for $x$ on the right-hand side of equation (4) produces the following geometric sequence: 


$$
\begin{aligned}
& x=A[A x+y]+y \\
& x=A[A\{A x+y\}+y]+y \\
& x=\left[I+A+A^{2}+A^{3}+\ldots+A^{\infty} x\right] y
\end{aligned}
$$

If the condition $\lim _{n \rightarrow \infty} A^{n}=0$ is satisfied, the system is productive and the non-negative solution is: ${ }^{5}$

$$
x=(1-A)^{-1} y
$$

where $(I-A)^{-1}$ is the matrix multiplier required.

Let $F$ denote the $(n \times k)$ matrix of energy requirements (in PJs), per unit of gross output, for $n$ industries across $k$ fossil fuel types. Let $e$ denote the k-element vector of $\mathrm{CO}_{2}$ emissions (tonnes of carbon dioxide) per unit of energy (PJ) associated with each of the $k$ fossil fuels.

Multiplying the transpose of the $e$ vector by the transpose of the $F$ matrix gives the following row vector which contains the carbon dioxide emissions per unit of gross output from each industry:

$$
e^{\prime} F^{\prime}=\left[e_{1} \ldots \ldots e_{k}\right]\left[\begin{array}{ccc}
f_{11} & \ldots & f_{n 1} \\
\vdots & & \vdots \\
f_{1 k} & \ldots & f_{n k}
\end{array}\right]
$$

Total carbon dioxide emissions, $E$, can then be obtained by post-multiplying the above row vector by the column vector of gross output, $x$ :

$$
\begin{aligned}
& E=e^{\prime} F^{\prime} x \\
& E=\left[e^{\prime} F^{\prime}(1-A)^{-1}\right] y
\end{aligned}
$$

The term in square brackets gives the row vector, $c^{\prime}$, of carbon dioxide intensities:

$$
c^{\prime}=e^{\prime} F^{\prime}(I-A)^{-1}
$$

Equation (8) is used in determining the necessary structural changes to achieve a specified reduction in emissions. Proops et al (1993, pp.11-12) identified three main areas where a change in economic structure might give rise to reductions in carbon dioxide emissions. First, there are changes to final demands, $y$. Second, there are changes to the efficiency of fuel-use, $F$. Third, changes to the structure of inter-industry trading, $A$ can be made.

The objective is to minimise the disruption to industries with regard to one of these variables while achieving a specified reduction in emissions. Disruption to any variable, $z_{i}$ say, in industry $i$ is measured in terms of the proportional change in that variable, $\dot{z}_{i}$. In specifying an objective function, that is a measure of the aggregate disruption, Proops et

\footnotetext{
${ }^{5}$ This is given from the solution to the geometric matrix series $S=I+A+A^{2}+\ldots=(I-A)^{-1}$, which must be non-negative given that all elements of $A$ are either zero or positive. For the system to be productive it is not merely sufficient for (4) to have a solution. The convergence requirement is equivalent to the HawkinSimons conditions: see Dorfman, Samuelson and Solow (1958, p.215).
} 
al (1993, p.228) adopted a quadratic cost function. However, it is useful to consider the more general form given by:

$$
D=\frac{1}{\theta} \sum_{i=1}^{n} \dot{z}_{i}^{\theta}
$$

The term $\theta$ is simply a scaling factor which drops out in differentiation. This objective function assumes that there is an equal social cost associated with a 1 percentage point change in a certain variable, irrespective of the industry.

It might be suggested that there should be a weight attached to the different industries, according to each industry's proportional contribution to the total level of an appropriate variable, such as aggregate employment. However, the method discussed in the following subsection imposes constraints on such variables, so that further weighting is not necessary. Indeed, it can be shown that such further weighting is not possible if the weighting mechanism desired uses the same variable as that already accounted for in the constraint.

\subsection{Disruptions to Final Demands}

\section{Carbon Dioxide Emissions Reduction Target}

Consider first the problem of minimising the disruption to final demand. To impose no more than a constraint on the reduction in carbon dioxide emissions is obviously not a case that should be considered seriously. In particular, the required final demand changes would all be negative. However, this case serves to introduce the basic approach adopted.

Total carbon dioxide emissions, when written in algebraic as opposed to matrix form are equal to $E=\sum_{i=1}^{n} c_{i} y_{i}$, so that the proportional change in emissions is:

$$
\frac{d E}{E}=\sum_{i=1}^{n}\left(\frac{c_{i} y_{i}}{\sum_{i=1}^{n} c_{i} y_{i}}\right) \frac{d y_{i}}{y}
$$

If $R$ is the required proportional change in total carbon dioxide emissions $\left[R=\frac{d E}{E}\right]$, the constraint can be written as:

$$
R=\sum_{i=1}^{n} w_{i} \dot{y}_{i}
$$

where $w_{i}$ is $i$ 's share of emissions, and $\dot{y}_{i}$ denotes the proportional change in final demand for industry $i$. The Lagrangean for this problem is given by:

$$
L=\frac{1}{\theta} \sum_{i=1}^{n} \dot{y}_{i}^{\theta}+\lambda\left[R-\sum_{i=1}^{n} w_{i} \dot{y}_{i}\right]
$$

Differentiation gives the set of first-order conditions:

$$
\dot{y}_{i}=\left(\lambda w_{i}\right)^{1 /(\theta-1)}
$$


Multiplying equation (14) by $w_{i}$, adding over all industries, and solving for $\lambda$ gives:

$$
\lambda=\left[\frac{R}{\sum_{i=1}^{n} w_{i}^{\theta /(\theta-1)}}\right]^{\theta-1}
$$

Substituting this result into the first-order condition gives the solution for the required proportional reduction in final demand of:

$$
\dot{y}_{i}=R\left[\frac{w_{i}^{1 /(\theta-1)}}{\sum_{i=1}^{n} w_{i}^{\theta /(\theta-1)}}\right]
$$

This result shows that the larger is $\theta$, the smaller is the dispersion in the required rates of change. Therefore, increasing the power ultimately leads toward an equalisation of the proportional changes. Furthermore, when additional constraints are imposed, the firstorder conditions cannot be solved explicitly. For this reason, the quadratic form is retained in this study, and the substitution of $\theta=2$ gives the result, as in Proops et al (1993, p.144), that:

$$
\dot{y}_{i}=R\left[\frac{w_{i}}{\sum_{i=1}^{n} w_{i}^{2}}\right]
$$

\section{Carbon Dioxide Emissions and GDP Growth Targets}

Suppose it is required to impose a constraint on GDP growth in addition to the constraint on the level of carbon dioxide emissions reduction. The rate of growth in GDP, $G$, can be written as:

$$
G=\sum_{i=1}^{n} w_{i}^{Y} \dot{y}_{i}
$$

The desired rate of growth is expressed as a weighted sum of the changes in final demands, with each weight being the proportion of that industry's contribution to GDP, that is $w_{i}^{Y}=y_{i} / \sum_{i=1}^{n} y_{i}$. The Lagrangean for this problem is:

$$
L=\frac{1}{2} \sum_{i=1}^{n} \dot{y}_{i}^{2}+\lambda\left[R-\sum_{i=1}^{n} w_{i} \dot{y}_{i}\right]+\mu\left[G-\sum_{i=1}^{n} w_{i}^{Y} \dot{y}_{i}\right]
$$

Differentiating with respect to each of the $\dot{y}_{i}$ gives rise to the first-order conditions:

$$
\frac{\partial L}{\partial \dot{y}_{i}}=\dot{y}_{i}-\lambda w_{i}-\mu w_{i}^{Y}=0
$$

along with the two constraints relating to $R$ and $G$. Using $\dot{y}_{i}=\lambda w_{i}+\mu w_{i}^{Y}$ from the firstorder conditions, and substituting into the constraints, gives the following two simultaneous equations expressed in matrix form as: 


$$
\left[\begin{array}{l}
R \\
G
\end{array}\right]=\left[\begin{array}{cc}
\sum_{i=1}^{n} w_{i}^{2} & \sum_{i=1}^{n} w_{i} w_{i}^{Y} \\
\sum_{i=1}^{n} w_{i} w_{i}^{Y} & \sum_{i=1}^{n}\left(w_{i}^{Y}\right)^{2}
\end{array}\right]\left[\begin{array}{l}
\lambda \\
\mu
\end{array}\right]
$$

If the determinant of the matrix on the right hand side of equation (21) is written as $\Delta$, the solutions for the Lagrange multipliers are:

$$
\left[\begin{array}{l}
\lambda \\
\mu
\end{array}\right]=\frac{1}{\Delta}\left[\begin{array}{c}
R \sum_{i=1}^{n}\left(w_{i}^{Y}\right)^{2}-G \sum_{i=1}^{n} w_{i} w_{i}^{Y} \\
-R \sum_{i=1}^{n} w_{i} w_{i}^{Y}+G \sum_{i=1}^{n} w_{i}^{2}
\end{array}\right]
$$

Finally, the resulting multipliers can be substituted into the first-order conditions to solve for the $\dot{y}_{i}$ s; see also Proops et al (1993, pp.234-235). ${ }^{6}$

\section{Carbon Dioxide Emissions, GDP Growth and Employment Growth Targets}

An additional constraint concerns the rate of growth in employment, $M$. This is expressed as:

$$
M=\sum_{i=1}^{n} w_{i}^{m} \dot{y}_{i}
$$

where the weights $w_{i}^{m}$ are the levels of employment in each industry as a proportion of total employment. Minimising the disruption to final demands subject to all three constraints simultaneously, involves the Lagrangean:

$$
L=\frac{1}{2} \sum_{i=1}^{n} \dot{y}_{i}^{2}+\lambda\left[R-\sum_{i=1}^{n} w_{i} \dot{y}_{i}\right]+\mu\left[G-\sum_{i=1}^{n} w_{i}^{Y} \dot{y}_{i}\right]+\gamma\left[M-\sum_{i=1}^{n} w_{i}^{m} \dot{y}_{i}\right]
$$

In this case there are three Lagrangean multipliers, so that a set of three linear equations needs to be solved using matrix methods. The procedure is a simple extension of that described above, although it involves the inverse of a $(3 \times 3)$ matrix; see also Proops et al (1993, pp.238-9).

\subsection{Disruptions to Fuel-Use Coefficients}

As an alternative to reducing outputs, carbon dioxide emissions can also be reduced by changing the amount of fuel used in production. Thus, instead of simply minimising changes to the vector of final demands, consider minimising the change in fuel-use coefficients subject to a carbon dioxide emissions reduction target. The direct fuel-use coefficients are embodied in the matrix, $F$. The objective is to minimise:

\footnotetext{
${ }^{6}$ If weights equal to the proportional contribution of each industry to total GDP are attached to $\dot{y}_{i}^{2}$, the Lagrangean multipliers are not identified. That is, the constraints on the carbon dioxide emission target and the rate of growth of GDP, $R$ and $G$, become equal to the sums of the Lagrangean multipliers, thus illustrating how additional weighting is not appropriate.
} 


$$
D=\frac{1}{2} \sum_{i=1}^{n} \sum_{j=1}^{K} \dot{f}_{i j}^{2}
$$

where $f_{i j}$ represents the proportional change in the production fuel requirement per unit of total demand of fuel $j$ in industry $i$. The change is minimised subject to the constraint that a target proportional reduction, $R_{F}$, in carbon dioxide emissions, attributable to changes in the production fuel-use coefficients, is achieved. Given that total emissions are $E=\sum_{i=1}^{n} \sum_{j=1}^{K} f_{i j} e_{j} x_{i}$, differentiation gives:

$$
\frac{d E}{E}=\sum_{i=1}^{n} \sum_{j=1}^{K} \frac{f_{i j} e_{j} x_{i}}{E} \frac{d f_{i j}}{f_{i j}}
$$

The target reduction in carbon dioxide emissions can then be expressed as:

$$
R_{F}=\sum_{i=1}^{n} \sum_{j=1}^{K} w_{i j} \dot{f}_{i j}
$$

Hence $R_{F}$ is a weighted row and column sum of the changes in the production fuel-use coefficients, with each weight given by $w_{i j}=f_{i j} e_{j} x_{i} / E$, which is the proportional contribution of fuel $j$ to carbon dioxide emissions by industry $i$. The Lagrangean is therefore:

$$
L=\frac{1}{2} \sum_{i=1}^{n} \sum_{j=1}^{K} \dot{f}_{i j}^{2}+\lambda\left[R_{F}-\sum_{i=1}^{n} \sum_{j=1}^{K} w_{i j} \dot{f}_{i j}\right]
$$

Following Proops et al (1993, pp.241, 144), solving this yields:

$$
\dot{f}_{i j}=\left[\frac{w_{i j}}{\sum_{i=1}^{n} \sum_{j=1}^{K} w_{i j}^{2}}\right] R_{F}
$$

The following sections apply these results to New Zealand. 


\section{Fuel Use and Carbon Content in New Zealand}

This section outlines the New Zealand data and the approach used to evaluate the expressions derived in the previous section.

The "Inter Industry Study of 1996" from New Zealand's System of National Accounts provided inter-industry flows in value terms for a 49 Industry Group Classification (IGC). This is the most recent year for which data are available. These flows were divided by each industry's gross output to produce the direct requirement coefficients which were then collected to form the $(49 \times 49) A$ matrix. By subtracting each industry's intermediate output from their gross output, the Accounts were also used to compile the 49-element $y$ vector of final demands.

The $F$ matrix was constructed from New Zealand's Energy Flow Accounts which provided the energy use arising from the fossil fuels, expressed in physical terms (PJs). These data are for the year ended March 1996 and are based on the Energy Account Industry Classification (EAIC). The use of a different classification from that used to construct the $A$ matrix means that a method of translation between the two classifications must be used. The translation between the Energy Account Industry Classification (EAIC) and the 49 Industry Group Classification (IGC) used for the analysis is provided in Table A1. Only those fuels for which at least one industry recorded a positive expenditure were incorporated, which provided nine fossil fuels for analysis. Table A2 provides information about the demands for these fuels which are expressed in physical terms and based on the 49 Industry Group Classification (IGC). Dividing these figures by each industry's gross output provided the required elements of the $(49 \times 9) F$ matrix.

Compiling the 9-element $e$ vector of carbon dioxide emissions entailed obtaining data from multiple sources. Table 1 displays the carbon dioxide emission factors for each of the nine fossil fuels analysed, along with their sources.

Table 1 - Carbon Dioxide Emission Factors: Tonnes / PJ

\begin{tabular}{lcl}
\hline Fuel & $\mathrm{CO}_{2}$ Emissions & Source \\
\hline Coal & 90,010 & Statistics NZ (1993, Table 4.5, p21) \\
Lignite & 95,200 & Statistics NZ (1993, Table 4.5, p21) \\
Crude Petroleum & 65,100 & Taylor et al (1993, Table 6.6, p35) \\
Natural Gas & 52,600 & MED (2003, Table A.1.1, p114) \\
LPG & 60,400 & Baines (1993, Table 5.7, p30) \\
Petrol & 66,600 & Baines (1993, Table 6.6, p35) \\
Diesel & 68,700 & Baines (1993, Table 6.6, p35) \\
Fuel Oil & 73,700 & Baines (1993, Table 6.6, p35) \\
Aviation Fuels \& Kerosene & 68,700 & Baines (1993, Table 6.6, p35) \\
\hline
\end{tabular}

The resulting values of $e, F$ and $A$ were used to calculate the 49-element $c$ vector of carbon dioxide intensities, using the expression $c^{\prime}=e^{\prime} F^{\prime}(I-A)^{-1}$ derived in subsection 2.1. 


\section{Minimum Disruption Calculations}

This section applies to New Zealand the minimum disruption approach described in section 2. Subsection 4.1 considers final demand changes while subsection 4.2 examines changes in fuel use.

\subsection{Disruptions to Final Demands}

The main results regarding final demand changes are provided in Table 2, which gives the annual changes to the elements of the final demand vector, $y$, which minimise disruptions to final demand while satisfying the constraints described. All values are expressed in percentage terms. In addition, Table 2 shows the final demand for each industry's output, the carbon intensity of the output and the proportion of the labour force employed by each industry.

The carbon intensities are measured in terms of the carbon content per dollar of final demand. It is not surprising that Petroleum and Industrial Chemical Manufacturing (IGC Code 18), which demands the greatest quantity of fuel across all industries, recorded by far the highest carbon content of 3.64 tonnes of carbon dioxide per dollar. Rubber, Plastic and Other Chemical Product Manufacturing (IGC Code 19) and Basic Metal Manufacturing (IGC Code 21), which respectively demand the largest quantities of natural gas and coal, record similarly high carbon contents of 1.83 and 1.40 tonnes of carbon dioxide per dollar. The only other industry to record a carbon content in excess of 1 , is Electricity Generation and Supply (IGC Code 26) with a value of 1.21.

\section{Carbon Dioxide Emissions Reduction Target}

Column 4 of Table 2, labelled ' $R$ Only', represents the results of the minimum disruption approach where the only constraint imposed is a 1 percentage point reduction in total carbon dioxide emissions. The changes in final demand required to achieve, for example, a 2 percentage point reduction in emissions are simply double those for the 1 percent case. With no constraint imposed on growth or employment, all industries are required to reduce their final demand. These annual reductions are proportional to the carbon dioxide emissions shares of each industry, as seen from equation (17), which in turn depend on final demands as well as carbon intensities. There is no simple relationship between carbon intensities and required reductions in final demand, as shown in Figure 1. The number corresponding to each dot in the figure indicates the Industry Group Classification Code (though it is only possible to show a proportion of these numbers). Nevertheless, the largest required annual rate of reduction in final demand is for Petroleum and Industrial Chemical Manufacturing (IGC Code 18) at -2.141 percent, followed by Rubber, Plastic and Other Chemical Product Manufacturing (IGC Code 19) at -1.491 percent and Construction (IGC Code 29) at -1.462 percent. Basic Metal Manufacturing (IGC Code 21) has the third highest carbon intensity but requires a much smaller reduction in final demand than several industries with lower intensities, because of its low weight.

As mentioned in section 2, these reductions should not be viewed as realistic values to be pursued, but instead benchmarks against which later results may be compared. 
Table 2 - Minimum Disruption Changes to Final Demand

\begin{tabular}{|c|c|c|c|c|c|c|c|c|c|c|}
\hline \multirow{3}{*}{$\begin{array}{l}\text { IGC } \\
\text { Code }\end{array}$} & \multirow{3}{*}{ IGC Description } & \multirow{3}{*}{$\begin{array}{c}\text { Final } \\
\text { Demand }\end{array}$} & \multirow{3}{*}{$\begin{array}{l}\text { Carbon } \\
\text { Intensity }\end{array}$} & \multirow{3}{*}{$\begin{array}{l}\text { Employment } \\
\text { Weight }\end{array}$} & \multicolumn{3}{|c|}{$R=-0.01$} & \multicolumn{3}{|c|}{$R=-0.02$} \\
\hline & & & & & $R$ Only & $G=0.02$ & $G=0.02$ & $G=0.02$ & $G=0.015$ & $G=0.02$ \\
\hline & & & & & & & $E=0.02$ & & $E=0.015$ & $E=0.02$ \\
\hline 1 & Horticulture and Fruit Growing & 896,214 & 0.96 & 0.017 & -0.472 & -1.3425 & -0.7122 & -2.0309 & -1.2052 & -1.3886 \\
\hline 2 & Livestock and Cropping Farming & 213,229 & 0.40 & 0.034 & -0.047 & 0.0077 & 1.3626 & -0.0260 & 1.3268 & 1.3320 \\
\hline 3 & Dairy Cattle Farming & 213,893 & 0.40 & 0.017 & -0.047 & 0.0096 & 0.6760 & -0.0235 & 0.6405 & 0.6460 \\
\hline 4 & Other Farming & 161,922 & 0.58 & 0.001 & -0.051 & -0.0715 & -0.0837 & -0.1278 & -0.1302 & -0.1377 \\
\hline 5 & $\begin{array}{l}\text { Services to Agriculture, Hunting and } \\
\text { Trapping }\end{array}$ & 111,614 & 0.68 & 0.007 & -0.042 & -0.0811 & -0.0852 & -0.1326 & -0.1254 & -0.1354 \\
\hline 6 & Forestry and Logging & $1,127,374$ & 0.34 & 0.005 & -0.208 & 0.2545 & 0.1646 & 0.1615 & 0.0286 & 0.0880 \\
\hline 7 & Fishing & 173,891 & 0.68 & 0.002 & -0.065 & -0.1255 & -0.1379 & -0.2053 & -0.1999 & -0.2153 \\
\hline 8 & Mining and Quarrying & 367,660 & 0.41 & 0.003 & -0.083 & 0.0057 & -0.0225 & -0.0553 & -0.0862 & -0.0783 \\
\hline 9 & Oil and Gas Exploration and Extraction & 229,624 & 0.23 & 0.000 & -0.029 & 0.1206 & 0.1014 & 0.1291 & 0.0909 & 0.1133 \\
\hline 10 & Meat and Meat Product Manufacturing & $4,150,526$ & 0.41 & 0.015 & -0.945 & 0.0335 & -0.2953 & -0.6680 & -1.0210 & -0.9370 \\
\hline 11 & Dairy Product Manufacturing & $4,174,399$ & 0.58 & 0.006 & -1.324 & -1.8512 & -2.1799 & -3.3065 & -3.3793 & -3.5762 \\
\hline 12 & Other Food Manufacturing & $3,370,380$ & 0.43 & 0.015 & -0.795 & -0.1136 & -0.3781 & -0.7392 & -1.0026 & -0.9553 \\
\hline 13 & Beverage, Malt and Tobacco Manufacturing & $1,171,464$ & 0.31 & 0.003 & -0.198 & 0.3569 & 0.2619 & 0.2971 & 0.1437 & 0.2193 \\
\hline 14 & Textile and Apparel Manufacturing & $1,854,639$ & 0.25 & 0.016 & -0.258 & 0.8435 & 0.6995 & 0.8596 & 0.5814 & 0.7427 \\
\hline 15 & Wood Product Manufacturing & 877,534 & 0.39 & 0.010 & -0.188 & 0.0667 & 0.0015 & -0.0580 & -0.1373 & -0.1106 \\
\hline 16 & Paper and Paper Product Manufacturing & $1,357,094$ & 0.40 & 0.006 & -0.297 & 0.0728 & -0.0344 & -0.1320 & -0.2563 & -0.2196 \\
\hline 17 & Printing, Publishing and Recorded Media & 594,218 & 0.28 & 0.015 & -0.090 & 0.2337 & 0.1944 & 0.2244 & 0.1471 & 0.1934 \\
\hline 18 & $\begin{array}{l}\text { Petroleum and Industrial Chemical } \\
\text { Manufacturing }\end{array}$ & $1,069,290$ & 3.64 & 0.003 & -2.141 & -9.5474 & -9.5919 & -13.5292 & -12.1604 & -13.5655 \\
\hline 19 & $\begin{array}{l}\text { Rubber, Plastic and Other Chemical Product } \\
\text { Manufacturing }\end{array}$ & $1,478,374$ & 1.83 & 0.011 & -1.491 & -5.8031 & -5.8915 & -8.3660 & -7.5995 & -8.4377 \\
\hline 20 & Non-Metallic Mineral Product Manufacturing & 144,620 & 0.66 & 0.004 & -0.052 & -0.0958 & -0.1042 & -0.1588 & -0.1538 & -0.1654 \\
\hline 21 & Basic Metal Manufacturing & 671,546 & 1.40 & 0.005 & -0.516 & -1.8257 & -1.8692 & -2.6676 & -2.4431 & -2.7028 \\
\hline 22 & $\begin{array}{l}\text { Structural, Sheet and Fabricated Metal } \\
\text { Product Manufacturing }\end{array}$ & 761,224 & 0.37 & 0.017 & -0.155 & 0.0981 & 0.0473 & 0.0061 & -0.0634 & -0.0341 \\
\hline 23 & Transport Equipment Manufacturing & $1,629,210$ & 0.23 & 0.006 & -0.202 & 0.8661 & 0.7338 & 0.9300 & 0.6615 & 0.8218 \\
\hline 24 & Machinery and Equipment Manufacturing & $2,805,651$ & 0.29 & 0.019 & -0.452 & 0.9610 & 0.7407 & 0.8601 & 0.4837 & 0.6806 \\
\hline 25 & Furniture and Other Manufacturing & 977,413 & 0.29 & 0.011 & -0.153 & 0.3566 & 0.2828 & 0.3301 & 0.1985 & 0.2704 \\
\hline
\end{tabular}




\begin{tabular}{|c|c|c|c|c|c|c|c|c|c|c|}
\hline \multirow{3}{*}{$\begin{array}{l}\text { IGC } \\
\text { Code }\end{array}$} & \multirow{3}{*}{ IGC Description } & \multirow{3}{*}{$\begin{array}{l}\text { Final } \\
\text { Demand }\end{array}$} & \multirow{3}{*}{$\begin{array}{l}\text { Carbon } \\
\text { Intensity }\end{array}$} & \multirow{3}{*}{$\begin{array}{l}\text { Employment } \\
\text { Weight }\end{array}$} & \multicolumn{3}{|c|}{$R=-0.01$} & \multicolumn{3}{|c|}{$R=-0.02$} \\
\hline & & & & & $R$ Only & $G=0.02$ & $G=0.02$ & $G=0.02$ & $G=0.015$ & $G=0.02$ \\
\hline & & & & & & & $E=0.02$ & & $E=0.015$ & $E=0.02$ \\
\hline 26 & Electricity Generation and Supply & $1,256,515$ & 1.21 & 0.005 & -0.837 & -2.7632 & -2.8508 & -4.0787 & -3.7616 & -4.1503 \\
\hline 27 & Gas Supply & 188,335 & 0.36 & 0.001 & -0.037 & 0.0307 & 0.0157 & 0.0105 & -0.0099 & -0.0017 \\
\hline 28 & Water Supply & 720 & 0.26 & 0.001 & 0.000 & 0.0003 & 0.0008 & 0.0003 & 0.0007 & 0.0008 \\
\hline 29 & Construction & $8,246,331$ & 0.32 & 0.066 & -1.462 & 2.1587 & 1.5212 & 1.5971 & 0.5994 & 1.0789 \\
\hline 30 & Wholesale Trade & $7,874,809$ & 0.24 & 0.049 & -1.031 & 3.8996 & 3.2738 & 4.0945 & 2.8520 & 3.5844 \\
\hline 31 & Retail Trade & $8,105,204$ & 0.24 & 0.130 & -1.086 & 3.8902 & 3.3003 & 4.0416 & 2.8326 & 3.5684 \\
\hline 32 & Accommodation, Restaurants and Bars & $2,859,420$ & 0.26 & 0.044 & -0.412 & 1.2253 & 1.0166 & 1.2202 & 0.8150 & 1.0526 \\
\hline 33 & Road Transport & 456,138 & 0.35 & 0.017 & -0.088 & 0.0819 & 0.0557 & 0.0359 & -0.0051 & 0.0159 \\
\hline 34 & Water and Rail Transport & 693,698 & 0.70 & 0.005 & -0.266 & -0.5385 & -0.5891 & -0.8722 & -0.8462 & -0.9133 \\
\hline 35 & $\begin{array}{l}\text { Air Transport, Services to Transport and } \\
\text { Storage }\end{array}$ & $3,001,753$ & 0.86 & 0.019 & -1.424 & -3.7048 & -3.9212 & -5.6955 & -5.3757 & -5.8716 \\
\hline 36 & Communication Services & $1,706,165$ & 0.07 & 0.018 & -0.063 & 1.6531 & 1.5192 & 2.0168 & 1.6290 & 1.9084 \\
\hline 37 & Finance & $1,181,042$ & 0.05 & 0.022 & -0.032 & 1.2017 & 1.1154 & 1.4764 & 1.2054 & 1.4074 \\
\hline 38 & Insurance & $1,205,743$ & 0.06 & 0.004 & -0.039 & 1.1942 & 1.0936 & 1.4615 & 1.1779 & 1.3792 \\
\hline 39 & Services to Finance and Insurance & 50,149 & 0.06 & 0.008 & -0.002 & 0.0497 & 0.0507 & 0.0608 & 0.0540 & 0.0624 \\
\hline 40 & Real Estate & $3,053,166$ & 0.06 & 0.012 & -0.109 & 2.9764 & 2.7226 & 3.6345 & 2.9243 & 3.4269 \\
\hline 41 & Ownership of Owner-Occupied Dwellings & $8,693,724$ & 0.07 & 0.000 & -0.311 & 8.4695 & 7.7241 & 10.3411 & 8.2982 & 9.7282 \\
\hline 42 & $\begin{array}{l}\text { Equipment Hire and Investors in Other } \\
\text { Property }\end{array}$ & 249,195 & 0.12 & 0.000 & -0.016 & 0.2059 & 0.1847 & 0.2448 & 0.1919 & 0.2274 \\
\hline 43 & Business Services & $1,561,393$ & 0.10 & 0.090 & -0.082 & 1.3895 & 1.3170 & 1.6733 & 1.3841 & 1.6218 \\
\hline 44 & $\begin{array}{l}\text { Central Government Administration, } \\
\text { Defence, Public Order and Safety Services }\end{array}$ & $5,158,249$ & 0.19 & 0.044 & -0.533 & 3.2718 & 2.8666 & 3.6848 & 2.7687 & 3.3556 \\
\hline 45 & $\begin{array}{l}\text { Local Government Administration Services } \\
\text { and Civil Defence }\end{array}$ & $2,537,488$ & 0.17 & 0.014 & -0.241 & 1.7173 & 1.5127 & 1.9634 & 1.4917 & 1.7965 \\
\hline 46 & Education & $4,272,040$ & 0.10 & 0.076 & -0.239 & 3.7313 & 3.4180 & 4.4797 & 3.5902 & 4.2290 \\
\hline 47 & Health and Community Services & $5,793,658$ & 0.15 & 0.072 & -0.474 & 4.3032 & 3.8607 & 5.0170 & 3.9066 & 4.6597 \\
\hline 48 & Cultural and Recreational Services & $2,047,472$ & 0.11 & 0.022 & -0.121 & 1.7534 & 1.5937 & 2.0983 & 1.6680 & 1.9689 \\
\hline 49 & Personal and Other Community Services & $1,158,033$ & 0.14 & 0.031 & -0.087 & 0.9006 & 0.8229 & 1.0593 & 0.8416 & 0.9982 \\
\hline
\end{tabular}


Figure 1 - Carbon Intensities and Changes in Final Demands with Reductions in Carbon Dioxide Emissions Only

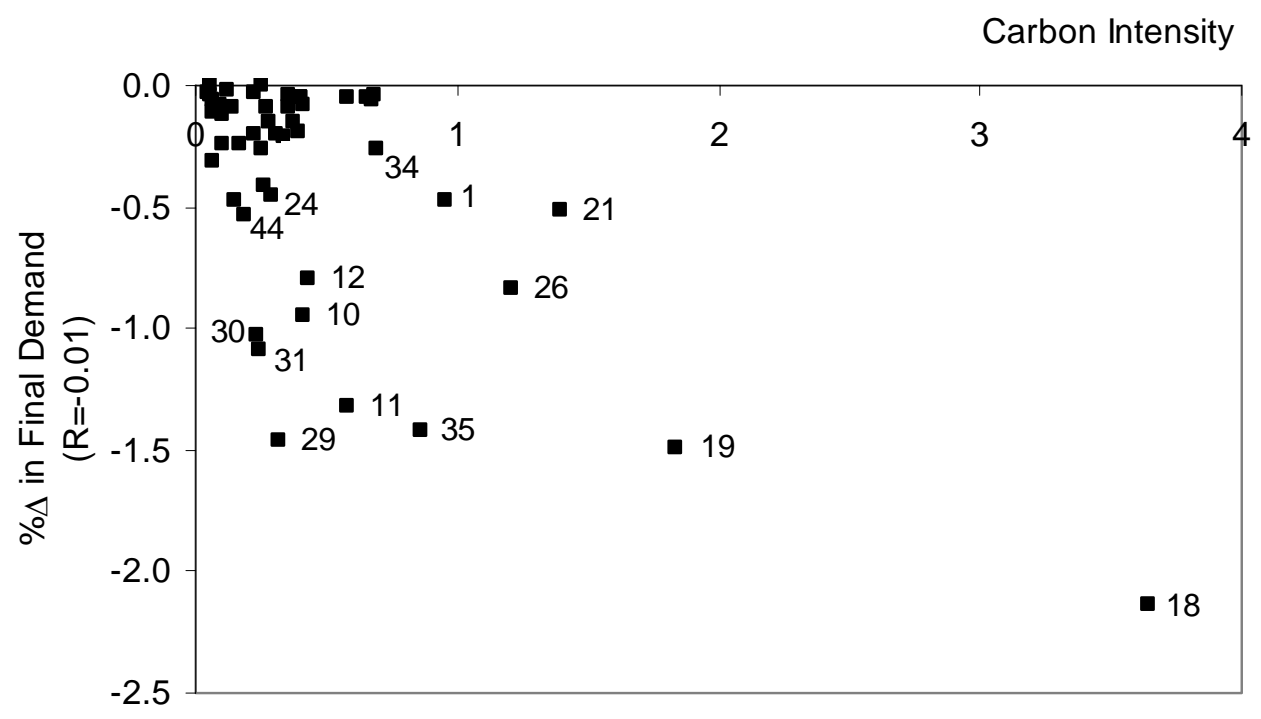

\section{Carbon Dioxide Emissions and GDP Growth Targets}

Column 5 of Table 2 reports the changes to final demand when 2 percent growth in GDP is imposed in addition to the 1 percentage point reduction in carbon dioxide emissions. The two constraints exert opposing influences on final demand. The GDP growth constraint prompts increases in final demand, while the carbon dioxide constraint necessitates reductions.

The objective function requires minimising the sum of the square of the proportionate changes in final demand of each industry. To achieve the GDP growth constraint, increasing the final demands of industries which have relatively larger final demands, gives smaller proportionate changes, thereby minimising the objective function. Figure 2 clearly shows the positive correlation between the final demand of an industry and its associated required change in final demand. Similarly, in achieving the carbon constraint, industries whose outputs have higher carbon contents achieve greater reductions in emissions for given reductions in final demand.

An industry's required change in final demand is therefore determined by balancing the carbon intensity of its output against the level of final demand. Accordingly, Ownership of Owner-Occupied Dwellings (IGC Code 41) which has the largest final demand coupled with one of the smallest carbon contents is required to achieve the largest increase in final demand of 8.4695 percent. Similarly, Health and Community Services (IGC Code 47), Wholesale Trade (IGC Code 30), Retail Trade (IGC Code 31) and Education (IGC Code 46) are all required to achieve substantial increases in final demand. All four of these industries may be classified as service industries which produce low carbon dioxide emissions, yet have high levels of final demand. The changes in final demand required by Retail and Wholesale trade (IGC Codes 30 and 31 respectively) and by Construction (IGC Code 29) contrast substantially with those required in the absence of a growth constraint.

Regarding industries required to reduce their final demand, Petroleum and Industrial Chemical Manufacturing (IGC Code 18) and Rubber, Plastic and Other Chemical Product Manufacturing (IGC Code 19), which have the two highest carbon intensities require the greatest reductions in final demand of respectively -9.5474 and -5.8031 percent. These 
are of course larger than when there is no GDP constraint, to compensate for the positive growth of other industries.

Figure 2 - Final Demands and Changes in Final Demands with Carbon Dioxide Emissions and GDP Growth Targets

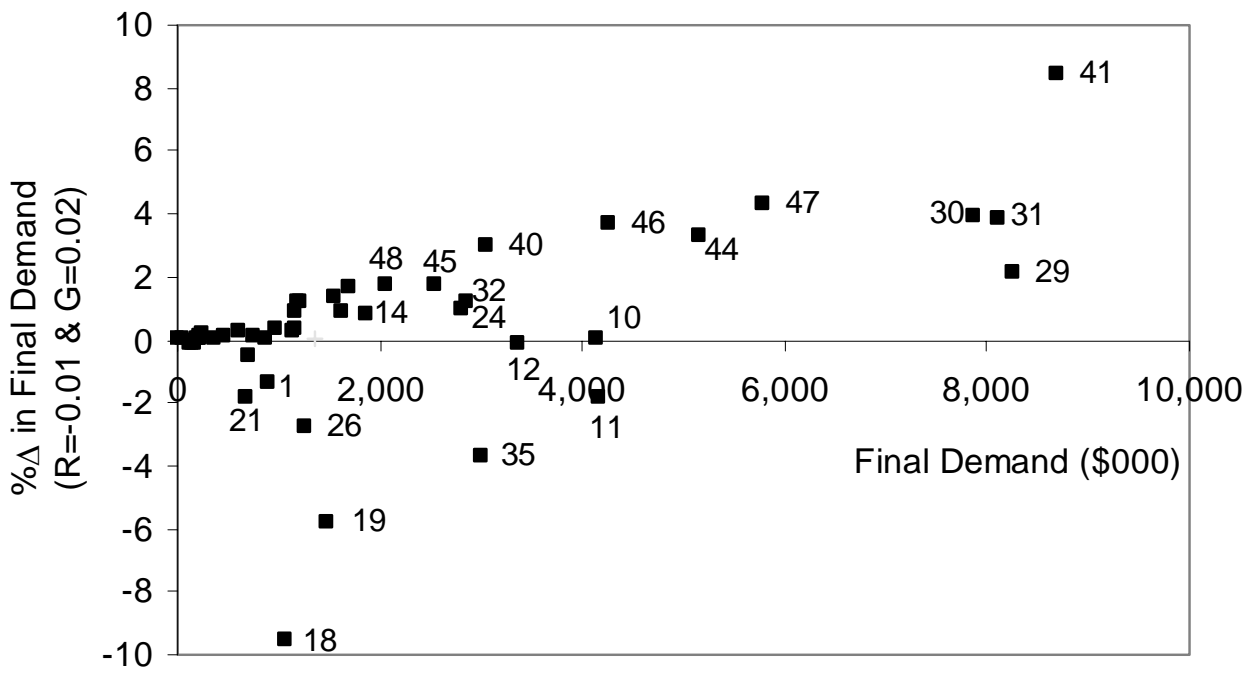

Column 7 of Table 2 shows the required changes to final demands when the required aggregate reduction in carbon dioxide emissions is raised from 1 to 2 percent, holding the GDP growth constraint constant. The addition of a GDP growth target removes the simple relationship between the proportional reductions in carbon dioxide emissions by each industry and the required aggregate percentage reduction in emissions. Variations in the changes to final demand which arise from raising the emissions constraint are displayed in Figure 3. If the points were all to lie on the 45 degree line, the higher emissions constraint would have no effect. However, as Figure 3 shows, the higher constraint requires greater reductions to be achieved in final demand. Consequently, increases in final demand must also be accentuated so as to achieve the growth constraint. These two effects combine to increase the spread of the distribution, thereby increasing the costs of disruption. However, the relative positions of the industries are seen to change only slightly. 
Figure 3 - Changes in Final Demands and Raising the $\mathrm{CO}_{2}$ Reduction Target

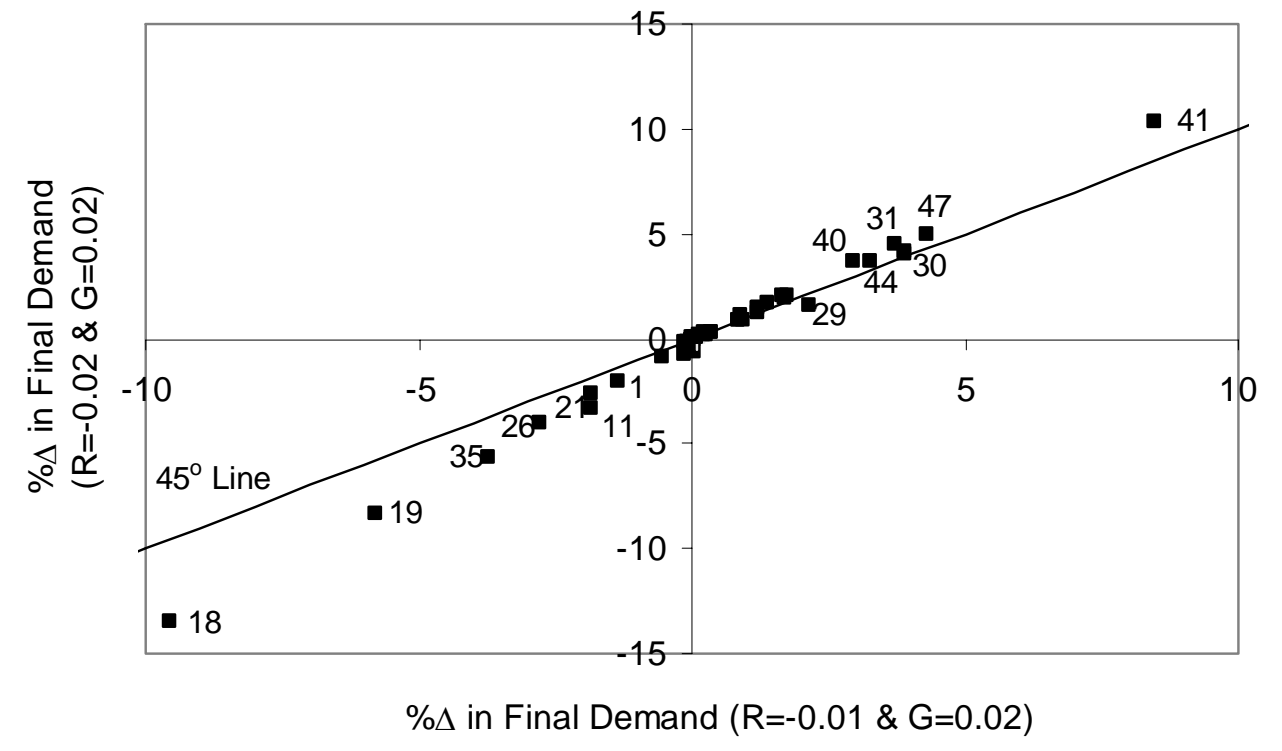

\section{Carbon Dioxide Emissions, GDP Growth and Employment Growth Targets}

Both employment and GDP growth targets, in addition to the 1 percentage point reduction in carbon dioxide emissions, were used to generate the results shown in column 6 of Table 2. A 2 percent growth constraint on both GDP and employment was also imposed by Proops et al (1993, p.252) 'so that the growing productivity of labour [could] be taken into account, without needing the labour coefficients to be altered'. As in Figure 3, Figure 4 displays the impact on the required changes to final demands caused by the employment constraint.

Figure 4 - Changes in Final Demands and Adding an Employment Growth Target

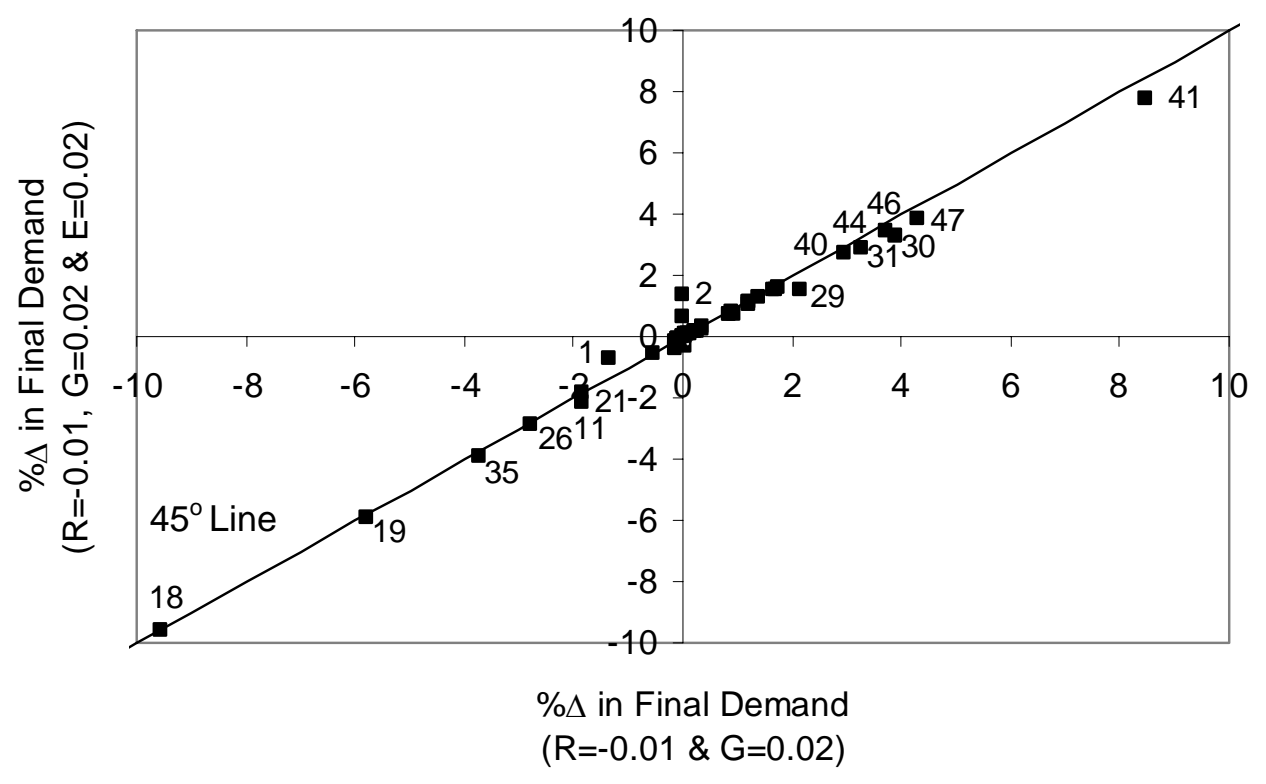


The additional employment constraint is seen to cause very little variation to the required changes in final demand. This should not be surprising as those industries which have the largest final demands and consequently employ the greatest proportion of workers also require the largest increases in final demands to achieve 2 percent growth in GDP. Furthermore, in achieving this growth, a certain level of growth in employment is essential. Consequently, making the employment constraint explicit makes very little difference to the required changes in final demand.

Shown in the final two columns of Table 2, and contrasted in Figure 5, are the minimum disruption changes to final demand which arise from respectively 1.5 and 2 percent growth targets for GDP and employment, holding constant a 2 percent reduction in carbon dioxide emissions. The higher growth rate of 2 percent necessitates greater increases in final demands, which are sought from those industries which already required the largest increases in the case of the 1.5 percent growth rate. The resulting rise in carbon dioxide emissions is countered primarily by Petroleum and Industrial Chemical Manufacturing (IGC Code18) and Rubber, Plastic and Other Chemical Product Manufacturing (IGC Code 19), which are required to further reduce their final demands by 1.4051 and 0.8382 percent respectively. These changes at the extremes of the distribution again increase the spread which leads to further increases in the cost of adjustment.

Figure 5 - Changes in Final Demands and Raising the GDP and Employment Growth Targets

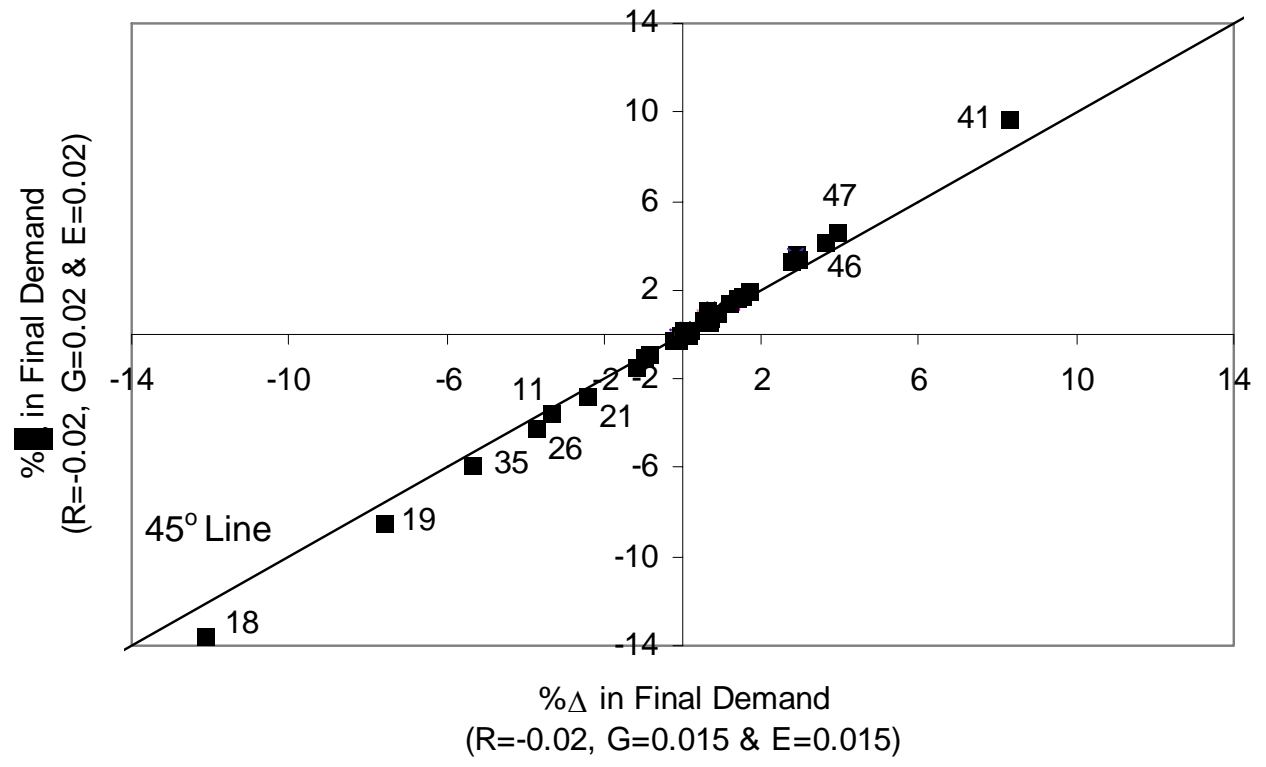

This result is magnified when the minimum disruptions of columns 6 and 9 are contrasted. Figure 6 shows the required changes to final demand in the case of 1 and 2 percent reductions in carbon dioxide emissions, holding constant 2 percent growth rates in GDP and employment. Achieving the 1 percentage point increase in the reduction in carbon dioxide emissions requires relatively greater changes in final demands than required to achieve the 0.5 percentage point increase in both growth rates. 
Figure 6 - Changes in Final Demands and Raising the $\mathrm{CO}_{2}$ Reduction Target with Growth and Employment Targets

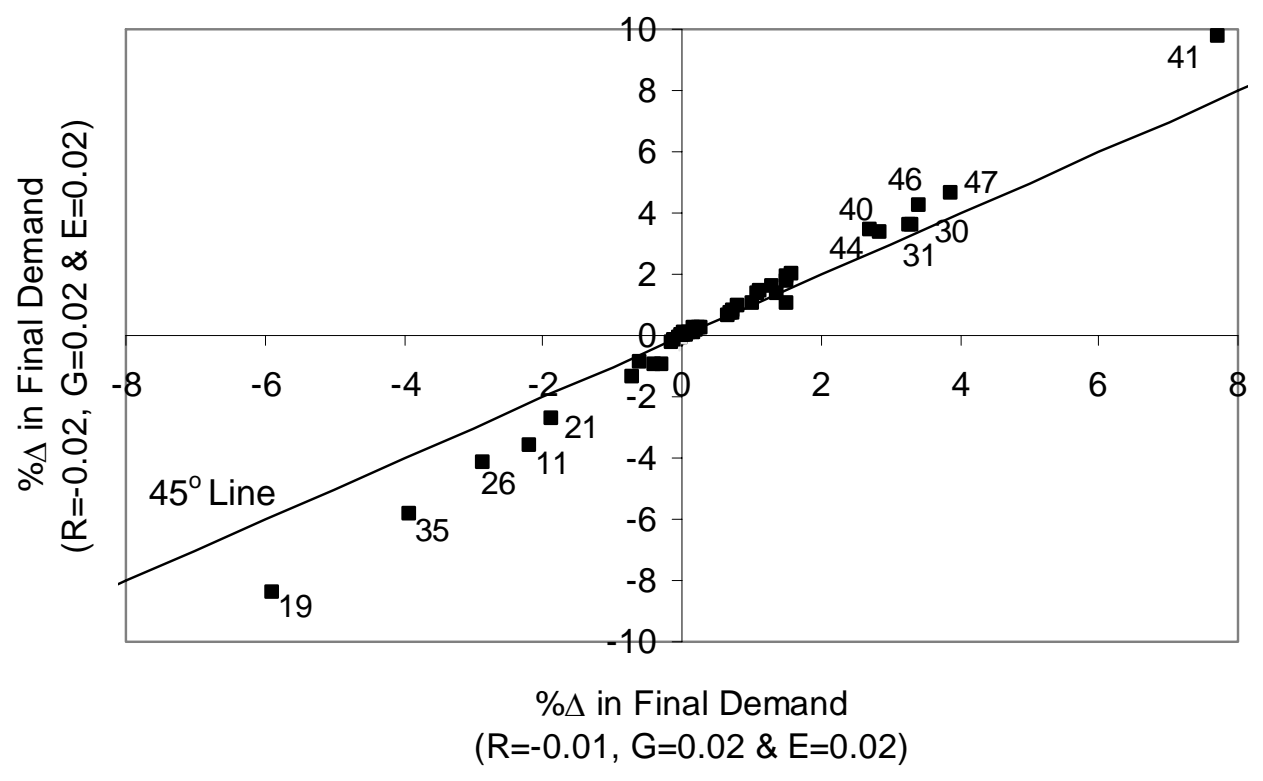

\subsection{Disruptions to Fuel-Use Coefficients}

This subsection examines the annual minimum disruption changes to fuel-use necessary to reduce carbon dioxide emissions by 1 percentage point. The elements of the $F$ matrix, which describe the quantity of fuel required per unit of gross output, vary subject only to the constraint on the reductions in carbon dioxide emissions being achieved. Consequently, the changes given in Table 3 are all non-positive values, which are again expressed in percentage terms. The changes required for a 2 percent reduction in carbon dioxide emissions are simply double those shown in Table 3 and for this reason are not reported.

The largest annual rate of change required is in the use of crude petroleum by Petroleum and Industrial Chemical Manufacturing (IGC Code 18). The only other required change over one percent is in the use of natural gas by Rubber, Plastic and Other Chemical Product Manufacturing (IGC Code 19). All other changes are either zero or negligible, suggesting that achieving a 1 percentage point reduction in carbon dioxide emissions purely through fuel substitution is feasible. 
Table 3 - Minimum Disruption Changes to Fuel-Use: $R=-0.01$

\begin{tabular}{|c|c|c|c|c|c|c|c|c|c|c|}
\hline \multirow{2}{*}{$\begin{array}{l}\text { IGC } \\
\text { Code }\end{array}$} & \multirow[t]{2}{*}{ IGC Description } & \multicolumn{9}{|c|}{ Percentage Changes in the $F$ Matrix } \\
\hline & & Coal & Lignite & $\begin{array}{l}\text { Crude } \\
\text { Petroleum }\end{array}$ & $\begin{array}{l}\text { Natural } \\
\text { Gas }\end{array}$ & LPG & Petrol & Diesel & Fuel Oil & $\begin{array}{l}\text { Aviation } \\
\text { Fuels \& } \\
\text { Kerosene }\end{array}$ \\
\hline 1 & Horticulture and Fruit Growing & 0 & 0 & 0 & 0 & 0 & -0.0870 & -0.1610 & 0 & -0.0010 \\
\hline 2 & Livestock and Cropping Farming & 0 & 0 & 0 & 0 & 0 & -0.0210 & -0.0380 & 0 & 0 \\
\hline 3 & Dairy Cattle Farming & 0 & 0 & 0 & 0 & 0 & -0.0210 & -0.0380 & 0 & 0 \\
\hline 4 & Other Farming & 0 & 0 & 0 & 0 & 0 & -0.0160 & -0.0290 & 0 & 0 \\
\hline 5 & Services to Agriculture, Hunting and Trapping & 0 & 0 & 0 & -0.0060 & 0 & -0.0110 & -0.0720 & -0.0070 & 0 \\
\hline 6 & Forestry and Logging & 0 & 0 & 0 & 0 & 0 & -0.0110 & -0.0280 & 0 & 0 \\
\hline 7 & Fishing & 0 & 0 & 0 & -0.0100 & 0 & 0 & -0.0810 & -0.0110 & 0 \\
\hline 8 & Mining and Quarrying & -0.0110 & 0 & 0 & 0 & 0 & -0.0030 & -0.0240 & -0.0030 & 0 \\
\hline 9 & Oil and Gas Exploration and Extraction & -0.0070 & 0 & 0 & 0 & 0 & -0.0020 & -0.0150 & -0.0020 & 0 \\
\hline 10 & Meat and Meat Product Manufacturing & -0.0530 & -0.0080 & 0 & -0.0160 & -0.0060 & -0.0070 & -0.0020 & -0.0030 & 0 \\
\hline 11 & Dairy Product Manufacturing & -0.1350 & -0.0200 & 0 & -0.0610 & -0.0010 & 0 & -0.0270 & -0.0090 & 0 \\
\hline 12 & Other Food Manufacturing & -0.0130 & -0.0020 & 0 & -0.0360 & -0.0080 & -0.0250 & -0.0160 & -0.0140 & 0 \\
\hline 13 & Beverage, Malt and Tobacco Manufacturing & -0.0040 & -0.0010 & 0 & -0.0120 & -0.0030 & -0.0090 & -0.0060 & -0.0050 & 0 \\
\hline 14 & Textile and Apparel Manufacturing & -0.0130 & -0.0020 & 0 & -0.0130 & -0.0010 & -0.0020 & -0.0090 & -0.0070 & 0 \\
\hline 15 & Wood Product Manufacturing & -0.0070 & -0.0010 & 0 & -0.0130 & -0.0010 & 0 & -0.0030 & -0.0130 & 0 \\
\hline 16 & Paper and Paper Product Manufacturing & -0.0130 & -0.0020 & 0 & -0.0360 & -0.0020 & 0 & -0.0010 & -0.0250 & 0 \\
\hline 17 & Printing, Publishing and Recorded Media & -0.0060 & -0.0010 & 0 & -0.0160 & -0.0010 & 0 & -0.0010 & -0.0110 & 0 \\
\hline 18 & Petroleum and Industrial Chemical Manufacturing & 0 & 0 & -2.5730 & 0 & 0 & 0 & 0 & 0 & 0 \\
\hline 19 & $\begin{array}{l}\text { Rubber, Plastic and Other Chemical Product } \\
\text { Manufacturing }\end{array}$ & -0.0070 & -0.0010 & 0 & -1.1790 & -0.0030 & -0.0020 & -0.0440 & -0.0110 & 0 \\
\hline 20 & Non-Metallic Mineral Product Manufacturing & -0.1000 & -0.0150 & 0 & -0.0150 & -0.0100 & 0 & -0.0060 & -0.0020 & 0 \\
\hline 21 & Basic Metal Manufacturing & -0.3240 & 0 & 0 & -0.1090 & -0.0060 & 0 & -0.0030 & -0.0420 & 0 \\
\hline 22 & $\begin{array}{l}\text { Structural, Sheet and Fabricated Metal Product } \\
\text { Manufacturing }\end{array}$ & 0 & 0 & 0 & -0.0020 & -0.0010 & -0.0010 & -0.0080 & -0.0010 & 0 \\
\hline 23 & Transport Equipment Manufacturing & -0.0010 & 0 & 0 & -0.0040 & -0.0030 & -0.0020 & -0.0170 & -0.0020 & 0 \\
\hline 24 & Machinery and Equipment Manufacturing & -0.0010 & 0 & 0 & -0.0070 & -0.0050 & -0.0030 & -0.0300 & -0.0030 & 0 \\
\hline
\end{tabular}




\begin{tabular}{|c|c|c|c|c|c|c|c|c|c|c|}
\hline \multirow{2}{*}{$\begin{array}{l}\text { IGC } \\
\text { Code }\end{array}$} & \multirow[t]{2}{*}{ IGC Description } & \multicolumn{9}{|c|}{ Percentage Changes in the $F$ Matrix } \\
\hline & & Coal & Lignite & $\begin{array}{c}\text { Crude } \\
\text { Petroleum }\end{array}$ & $\begin{array}{l}\text { Natural } \\
\text { Gas }\end{array}$ & LPG & Petrol & Diesel & Fuel Oil & $\begin{array}{l}\text { Aviation } \\
\text { Fuels \& } \\
\text { Kerosene }\end{array}$ \\
\hline 25 & Furniture and Other Manufacturing & -0.0020 & 0 & 0 & -0.0020 & 0 & -0.0020 & 0 & 0 & 0 \\
\hline 26 & Electricity Generation and Supply & -0.1240 & 0 & 0 & -0.6980 & 0 & -0.0010 & -0.0020 & 0 & 0 \\
\hline 27 & Gas Supply & -0.0050 & 0 & 0 & 0 & 0 & -0.0020 & -0.0120 & -0.0020 & 0 \\
\hline 28 & Water Supply & 0 & 0 & 0 & 0 & 0 & 0 & -0.0010 & 0 & 0 \\
\hline 29 & Construction & 0 & 0 & 0 & -0.0020 & -0.0090 & -0.0340 & -0.1280 & 0 & -0.0030 \\
\hline 30 & Wholesale Trade & -0.0180 & -0.0010 & 0 & -0.0050 & -0.0050 & -0.1690 & -0.0140 & -0.0010 & 0 \\
\hline 31 & Retail Trade & -0.0220 & -0.0010 & 0 & -0.0140 & -0.0060 & -0.1940 & -0.0140 & -0.0010 & 0 \\
\hline 32 & Accommodation, Restaurants and Bars & -0.0010 & 0 & 0 & -0.0130 & -0.0060 & -0.0120 & -0.0030 & -0.0100 & 0 \\
\hline 33 & Road Transport & 0 & 0 & 0 & -0.0030 & 0 & -0.0190 & -0.0390 & -0.0060 & -0.0640 \\
\hline 34 & Water and Rail Transport & 0 & 0 & 0 & -0.0040 & 0 & -0.0280 & -0.0600 & -0.0090 & -0.0970 \\
\hline 35 & Air Transport, Services to Transport and Storage & -0.0010 & 0 & 0 & -0.0170 & 0 & -0.1230 & -0.2580 & -0.0400 & -0.4200 \\
\hline 37 & Finance & 0 & 0 & 0 & -0.0010 & 0 & -0.0030 & 0 & -0.0010 & 0 \\
\hline 38 & Insurance & 0 & 0 & 0 & -0.0010 & 0 & -0.0030 & 0 & -0.0010 & 0 \\
\hline 39 & Services to Finance and Insurance & 0 & 0 & 0 & 0 & 0 & 0 & 0 & 0 & 0 \\
\hline 40 & Real Estate & 0 & 0 & 0 & -0.0020 & 0 & -0.0070 & 0 & -0.0020 & 0 \\
\hline 41 & Ownership of Owner-Occupied Dwellings & -0.0010 & 0 & 0 & -0.0060 & 0 & -0.0190 & 0 & -0.0060 & 0 \\
\hline 42 & Equipment Hire and Investors in Other Property & 0 & 0 & 0 & 0 & 0 & -0.0010 & 0 & 0 & 0 \\
\hline 43 & Business Services & 0 & 0 & 0 & -0.0010 & 0 & -0.0030 & 0 & -0.0010 & 0 \\
\hline 44 & $\begin{array}{l}\text { Central Government Administration, Defence, Public } \\
\text { Order and Safety Services }\end{array}$ & -0.0120 & -0.0010 & 0 & -0.0040 & 0 & -0.0110 & -0.0340 & -0.0420 & -0.0340 \\
\hline 45 & $\begin{array}{l}\text { Local Government Administration Services and Civil } \\
\text { Defence }\end{array}$ & -0.0010 & 0 & 0 & -0.0050 & 0 & -0.0160 & -0.0080 & 0 & 0 \\
\hline 46 & Education & -0.0290 & -0.0020 & 0 & -0.0070 & 0 & 0 & 0 & -0.0030 & 0 \\
\hline 47 & Health and Community Services & -0.0740 & -0.0040 & 0 & -0.0130 & 0 & -0.0140 & 0 & 0 & 0 \\
\hline 48 & Cultural and Recreational Services & -0.0010 & 0 & 0 & 0 & 0 & -0.0110 & 0 & -0.0010 & 0 \\
\hline 49 & Personal and Other Community Services & -0.0010 & 0 & 0 & 0 & 0 & -0.0060 & 0 & -0.0010 & 0 \\
\hline
\end{tabular}




\section{A Carbon Tax and Minimum Disruption Changes}

The above approach has produced changes in final demands for each industry which satisfy a required aggregate reduction in carbon dioxide emissions while minimising the value of a cost function (the sum of squared proportional changes in final demands). The analysis begs the question of how reductions may in practice be achieved in a market system using, for example, a carbon tax. Such a tax, imposed on carbon dioxide emissions, would be expected to give rise to a set of price changes, the extent depending on the carbon intensity of each good. The overall required reduction in carbon dioxide emissions would thus be achieved largely by reductions in consumer demands arising from the price changes. ${ }^{7}$ The pattern of changes in final demands therefore depends on the carbon intensities, combined with all the own-price and cross-price demand elasticities.

Such a tax is unlikely to produce changes that coincide precisely with minimum disruption changes, even taking the closest case considered above, that is the benchmark situation where no employment or GDP growth constraint is imposed. This is easily seen in the extreme case where the carbon intensity of only one industry is positive. A carbon tax would only raise the price of that industry's output, but would affect the final demands of the other industries depending on the size of the aggregate cross-price demand elasticities. In contrast, the minimum disruption change would involve a reduction in the output of only the polluting industry.

The relationship between the two sets of changes can be examined in more detail as follows. Consider the use of a carbon tax imposed at the rate, $\alpha$, which is expressed as an amount per tonne of carbon dioxide. ${ }^{8}$ This is equivalent to an ad valorem tax-exclusive indirect tax rate on the output of industry $i$ of $\tau_{i}=\alpha c_{i}$, where $c_{i}$ is the carbon dioxide intensity of the industry's output as defined above. This implies a set of proportional price changes of $\dot{p}_{i}=\tau_{i}$. Define $\eta_{i j}$ as the aggregate demand elasticity of good $i$ with respect to a change in the price of good $j$. The proportional changes in final demands, (remembering that these are measured in terms of expenditures), may be denoted by $\dot{y}_{i}^{C}$, and are given by: ${ }^{9}$

$$
\begin{aligned}
& \dot{y}_{i}^{C}=\dot{p}_{i}+\sum_{j=1}^{n} \eta_{i j} \dot{p}_{j} \\
& \dot{y}_{i}^{C}=\alpha\left(c_{i}+\sum_{j=1}^{n} \eta_{i j} c_{j}\right)
\end{aligned}
$$

If, as before, $w_{i}=c_{i} y_{i} / \sum_{j=1}^{n} c_{j} y_{j}$ is the share of carbon dioxide emissions produced by industry $i$, the carbon tax rate that achieves the desired proportional reduction of $R$ in aggregate emissions is given by solving for $\alpha$ from:

\footnotetext{
${ }^{7}$ There may of course also be changes in intermediate requirements arising from the price changes.

${ }^{8} \mathrm{~A}$ tax rate of $\$ 10$ per tonne translates into a value of $\alpha=0.010$.

${ }^{9}$ For the derivation of this result, see for example Cornwell and Creedy (1997, pp. 62-63).
} 


$$
R=\sum_{i=1}^{n} w_{i} \dot{y}_{i}^{C}
$$

Substituting for $\dot{y}_{i}^{C}$ and rearranging gives:

$$
\alpha=\frac{R}{\sum_{i=1}^{n} w_{i}\left(c_{i}+\sum_{j=1}^{n} \eta_{i j} c_{j}\right)}
$$

Hence the proportional reductions arising from the carbon tax can be expressed as $\dot{y}_{i}^{C}=R \delta_{i}$ where:

$$
\delta_{i}=\frac{\left(c_{i}+\sum_{j=1}^{n} \eta_{i j} c_{j}\right)}{\sum_{i=1}^{n} w_{i}\left(c_{i}+\sum_{j=1}^{n} \eta_{i j} c_{j}\right)}
$$

By contrast, the minimum disruption changes are given, from above, by $\dot{y}_{i}^{M}=R \phi_{i}$, where:

$$
\phi_{i}=\frac{w_{i}}{\sum_{i=1}^{n} w_{i}^{2}}
$$

The two sets of reductions are similar only in the unlikely situation where:

$$
w_{i} \approx c_{i}+\sum_{j=1}^{n} \eta_{i j} c_{j}
$$

Allowance for GDP growth clearly introduces a role for aggregate income elasticities, further complicating the differences between the sets of final demand changes which achieve equivalent reductions in carbon dioxide emissions.

Nevertheless, there is likely to be a positive correlation between the two sets of changes, given that they are both heavily influenced by the carbon dioxide intensities. The minimum disruption changes are determined by the carbon intensities, modified by the influence of the share terms, $w_{i}$; the influence of those intensities is shown in Figure 1. The carbon tax changes are determined by the same intensities, which affect price changes, modified by the demand elasticities, and some high intensity goods may have relatively low elasticities. The size of the correlation is of course an empirical question involving extensive information about household demands, and therefore cannot be examined further here.

However, in principle a differential set of carbon taxes could be used to ensure that the reductions arising from demand adjustments correspond precisely to minimum disruption adjustments. Again, where no further constraints are imposed, equating the sets of changes gives the matrix equation:

$$
[I+\eta] \hat{\alpha} C=\dot{y}^{M}
$$

where $I$ is the unit matrix, $\hat{\alpha}$ is a square matrix with the vector of $\alpha \mathrm{s}$ along the leading diagonal, $\eta$ is a matrix of demand elasticities and $c$ and $\dot{y}^{M}$ are column vectors. The vector of required carbon tax rates can then be obtained from: 


$$
\hat{\alpha} C=[I+\eta]^{-1} \dot{y}^{M}
$$

It would be of interest, given a set of demand elasticities, to determine the extent to which carbon tax rates would need to differ among sectors in order to produce minimum disruption changes. 
This paper has examined the nature of the least disruptive changes in the New Zealand economy that are necessary to achieve a target annual rate of reduction in carbon dioxide emissions, using a cost function that depends on the sum of the squares of the proportionate changes in final demands. The paper followed the methods first developed by Proops et al (1993), and concentrates on changes in final consumer demands and changes in the quantities and mixture of fossil fuels used by industries. A situation in which target emission levels are achieved by reducing all final demands would imply an increase in aggregate unemployment and a negative growth rate of GDP. To overcome this problem, constraints on GDP and employment growth were imposed, implying that the final demands of some industries need to increase while other industries decline.

The magnitude of an industry's required change in final demand was found to be determined by the relative efficiency with which they could achieve the stated constraints. The carbon intensity of an industry's output was balanced against its employment weight and value of final demand. The small orders of magnitude which resulted from these calculations suggest that reducing carbon dioxide emissions is economically feasible. That is, reductions can be achieved while maintaining acceptable levels of key macroeconomic variables if structural change can be encouraged in the areas indicated by this study. Further employment was found to be essential in achieving the growth constraint. Consequently, the addition of an employment constraint was found to make a negligible difference to the changes in final demand. Raising the magnitudes of the constraints was found to increase the spread of the distribution, thereby increasing the costs of adjustment. An increase in the carbon constraint of one percentage point was found to increase this cost more than increasing each of the growth constraints by 0.5 percentage points.

The required changes in the fuel-use coefficients were also small, with only two industries required to reduce specific fuel demands by more than 1 percent to achieve a 1 percent reduction in carbon dioxide emissions. Again, this supports the conclusion that such reductions in carbon dioxide emissions are feasible. The paper also compared the nature of reductions obtained using a carbon tax with minimum disruption changes, and showed that, in principle, the required changes could be achieved using a differential set of carbon taxes. 


\section{Appendix}

Table A1 - Translation between the Energy Account Industry Classification (EAIC) and the 49 Industry Group Classification (IGC)

\begin{tabular}{|c|c|c|c|}
\hline $\begin{array}{l}\text { EAIC } \\
\text { Code }\end{array}$ & EAIC Description & $\begin{array}{l}\text { IGC } \\
\text { Code }\end{array}$ & IGC Description \\
\hline \multirow[t]{5}{*}{$\mathrm{A} 01$} & Agriculture & 1 & Horticulture and Fruit Growing \\
\hline & & 2 & Livestock and Cropping Farming \\
\hline & & 3 & Dairy Cattle Farming \\
\hline & & 4 & Other Farming \\
\hline & & 5 & $\begin{array}{l}\text { Services to Agriculture, Hunting and } \\
\text { Trapping }\end{array}$ \\
\hline \multirow[t]{2}{*}{$\mathrm{A} 02$} & Fishing and Hunting & 5 & $\begin{array}{l}\text { Services to Agriculture, Hunting and } \\
\text { Trapping }\end{array}$ \\
\hline & & 7 & Fishing \\
\hline A03 & Forestry and Logging & 6 & Forestry and Logging \\
\hline \multirow[t]{3}{*}{ A04 } & Extraction, Mining, Quarrying and & 8 & Mining and Quarrying \\
\hline & & 9 & Oil and Gas Exploration and Extraction \\
\hline & & 27 & Gas Supply \\
\hline B01 & $\begin{array}{l}\text { Petroleum Product Refining, Distribution } \\
\text { and Supply }\end{array}$ & 18 & $\begin{array}{l}\text { Petroleum and Industrial Chemical } \\
\text { Manufacturing }\end{array}$ \\
\hline B02 & $\begin{array}{l}\text { Electricity Generation, Distribution and } \\
\text { Supply }\end{array}$ & 26 & Electricity Generation and Supply \\
\hline $\mathrm{C01}$ & Slaughtering and Meat Processing & 10 & Meat and Meat Product Manufacturing \\
\hline $\mathrm{C} 02$ & Dairy Products & 11 & Dairy Product Manufacturing \\
\hline \multirow[t]{2}{*}{$\mathrm{CO3}$} & $\begin{array}{l}\text { Beverages, Tobacco, confectionery and } \\
\text { sugar, and other food }\end{array}$ & 12 & Other Food Manufacturing \\
\hline & & 13 & $\begin{array}{l}\text { Beverage, Malt and Tobacco } \\
\text { Manufacturing }\end{array}$ \\
\hline $\mathrm{CO4}$ & Textile, Apparel and Leather goods & 14 & Textile and Apparel Manufacturing \\
\hline C05 & Wood Processing and Wood Products & 15 & Wood Product Manufacturing \\
\hline \multirow[t]{2}{*}{$\mathrm{CO6}$} & $\begin{array}{l}\text { Paper and Paper Products, Printing and } \\
\text { Publishing }\end{array}$ & 16 & $\begin{array}{l}\text { Paper and Paper Product } \\
\text { Manufacturing }\end{array}$ \\
\hline & & 17 & $\begin{array}{l}\text { Printing, Publishing and Recorded } \\
\text { Media }\end{array}$ \\
\hline $\mathrm{CO7}$ & $\begin{array}{l}\text { Chemicals, Related Products and } \\
\text { Plastics }\end{array}$ & 19 & $\begin{array}{l}\text { Rubber, Plastic and Other Chemical } \\
\text { Product Manufacturing }\end{array}$ \\
\hline $\mathrm{C08}$ & $\begin{array}{l}\text { Concrete, Clay, Glass and Related } \\
\text { Minerals Manufacture }\end{array}$ & 20 & $\begin{array}{l}\text { Non-Metallic Mineral Product } \\
\text { Manufacturing }\end{array}$ \\
\hline C09 & Basic Metal Industries & 21 & Basic Metal Manufacturing \\
\hline \multirow[t]{3}{*}{$\mathrm{C} 10$} & $\begin{array}{l}\text { Fabricated Metal Products, Machinery } \\
\text { and Equipment }\end{array}$ & 22 & $\begin{array}{l}\text { Structural, Sheet and Fabricated Metal } \\
\text { Product Manufacturing }\end{array}$ \\
\hline & & 23 & Transport Equipment Manufacturing \\
\hline & & 24 & $\begin{array}{l}\text { Machinery and Equipment } \\
\text { Manufacturing }\end{array}$ \\
\hline
\end{tabular}




\begin{tabular}{|c|c|c|c|}
\hline $\begin{array}{l}\text { EAIC } \\
\text { Code }\end{array}$ & EAIC Description & $\begin{array}{l}\text { IGC } \\
\text { Code }\end{array}$ & IGC Description \\
\hline C11 & Other Manufacturing Industries & 25 & Furniture and Other Manufacturing \\
\hline $\mathrm{C} 12$ & Construction & 29 & Construction \\
\hline D01 & Water Works and Supply & 28 & Water Supply \\
\hline \multirow{2}{*}{ D02 } & Wholesale and Retail Trade - Non Food & 30 & Wholesale Trade \\
\hline & & 31 & Retail Trade \\
\hline D03 & Wholesale Trade - Food & 30 & Wholesale Trade \\
\hline D04 & Retail Trade - Food & 31 & Retail Trade \\
\hline D05 & Motels, Hotels, Guest Houses & 32 & Accommodation, Restaurants and Bars \\
\hline D06 & Communication & 36 & Communication Services \\
\hline \multirow[t]{7}{*}{ D07 } & $\begin{array}{l}\text { Finance, Insurance, Real Estate and } \\
\text { Business Services }\end{array}$ & 37 & Finance \\
\hline & & 38 & Insurance \\
\hline & & 39 & Services to Finance and Insurance \\
\hline & & 40 & Real Estate \\
\hline & & 41 & $\begin{array}{l}\text { Ownership of Owner-Occupied } \\
\text { Dwellings }\end{array}$ \\
\hline & & 42 & $\begin{array}{l}\text { Equipment Hire and Investors in Other } \\
\text { Property }\end{array}$ \\
\hline & & 43 & Business Services \\
\hline D08 & Central Government Administration & 44 & $\begin{array}{l}\text { Central Government Administration, } \\
\text { Defence, Public Order and Safety } \\
\text { Services }\end{array}$ \\
\hline D09 & Central Government Defence Services & 44 & $\begin{array}{l}\text { Central Government Administration, } \\
\text { Defence, Public Order and Safety } \\
\text { Services }\end{array}$ \\
\hline D10 & Local Government Administration & 45 & $\begin{array}{l}\text { Local Government Administration } \\
\text { Services and Civil Defence }\end{array}$ \\
\hline D11 & $\begin{array}{l}\text { Education Services: Pre-School, } \\
\text { Primary and Secondary }\end{array}$ & 46 & Education \\
\hline D12 & Education Services: Tertiary Education & 46 & Education \\
\hline D13 & Health and Welfare Services & 47 & Health and Community Services \\
\hline \multirow[t]{2}{*}{ D14 } & $\begin{array}{l}\text { Other Social and Related Community } \\
\text { Services }\end{array}$ & 48 & Cultural and Recreational Services \\
\hline & & 49 & $\begin{array}{l}\text { Personal and Other Community } \\
\text { Services }\end{array}$ \\
\hline D15 & Sanitary and Cleaning Services & 45 & $\begin{array}{l}\text { Local Government Administration } \\
\text { Services and Civil Defence }\end{array}$ \\
\hline E01 & Domestic Transport and Storage & $\begin{array}{l}33 \\
34 \\
35\end{array}$ & $\begin{array}{l}\text { Road Transport } \\
\text { Water and Rail Transport } \\
\text { Air Transport, Services to Transport } \\
\text { and Storage }\end{array}$ \\
\hline
\end{tabular}

Statistics New Zealand provided fuel demands based on the EAIC. The above translation was used to convert the fuel demands to the 49 IGC. Where an industry from the EAIC incorporated multiple IGC industries, final demand was used as a weight to distribute the fuel demand of the EAIC industry to each of the IGC industries. 
Table A2 - Fuel Demands by Industry Group Classification (IGC) for the Year Ended March 1996 (Gross PJ)

\begin{tabular}{|c|c|c|c|c|c|c|c|c|c|}
\hline $\begin{array}{l}\text { IGC } \\
\text { Code }\end{array}$ & Coal & Lignite & $\begin{array}{l}\text { Crude } \\
\text { Petroleum }\end{array}$ & $\begin{array}{l}\text { Natural } \\
\text { Gas }\end{array}$ & LPG & Petrol & Diesel & Fuel Oil & $\begin{array}{l}\text { Aviation } \\
\text { Fuels \& } \\
\text { Kerosene }\end{array}$ \\
\hline 1 & 0 & 0 & 0 & 0.017 & 0 & 5.029 & 9.032 & 0.014 & 0.070 \\
\hline 2 & 0 & 0 & 0 & 0.004 & 0 & 1.197 & 2.149 & 0.003 & 0.017 \\
\hline 3 & 0 & 0 & 0 & 0.004 & 0 & 1.200 & 2.156 & 0.003 & 0.017 \\
\hline 4 & 0 & 0 & 0 & 0.003 & 0 & 0.909 & 1.632 & 0.003 & 0.013 \\
\hline 5 & 0 & 0 & 0 & 0.466 & 0 & 0.631 & 4.029 & 0.374 & 0.009 \\
\hline 6 & 0 & 0 & 0 & 0 & 0 & 0.635 & 1.564 & 0 & 0 \\
\hline 7 & 0 & 0 & 0 & 0.723 & 0 & 0.008 & 4.525 & 0.580 & 0 \\
\hline 8 & 0.454 & 0 & 0 & 0.012 & 0 & 0.171 & 1.333 & 0.179 & 0 \\
\hline 9 & 0.284 & 0 & 0 & 0.007 & 0 & 0.107 & 0.832 & 0.112 & 0 \\
\hline 10 & 2.273 & 0.318 & 0 & 1.184 & 0.412 & 0.403 & 0.099 & 0.138 & 0 \\
\hline 11 & 5.784 & 0.808 & 0 & 4.455 & 0.045 & 0.001 & 1.524 & 0.457 & 0 \\
\hline 12 & 0.537 & 0.075 & 0 & 2.602 & 0.504 & 1.434 & 0.925 & 0.715 & 0 \\
\hline 13 & 0.187 & 0.026 & 0 & 0.905 & 0.175 & 0.498 & 0.321 & 0.248 & 0 \\
\hline 14 & 0.557 & 0.078 & 0 & 0.962 & 0.047 & 0.140 & 0.504 & 0.383 & 0 \\
\hline 15 & 0.310 & 0.043 & 0 & 0.936 & 0.043 & 0.008 & 0.149 & 0.677 & 0 \\
\hline 16 & 0.572 & 0.080 & 0 & 2.649 & 0.150 & 0.006 & 0.083 & 1.310 & 0 \\
\hline 17 & 0.251 & 0.035 & 0 & 1.160 & 0.066 & 0.002 & 0.036 & 0.573 & 0 \\
\hline 18 & 0 & 0 & 152.267 & 0 & 0 & 0 & 0 & 0 & 0 \\
\hline 19 & 0.279 & 0.039 & 0 & 86.372 & 0.193 & 0.116 & 2.467 & 0.566 & 0 \\
\hline 20 & 4.272 & 0.597 & 0 & 1.134 & 0.645 & 0 & 0.346 & 0.094 & 0 \\
\hline 21 & 13.862 & 0 & 0 & 7.955 & 0.392 & 0.007 & 0.160 & 2.191 & 0 \\
\hline 22 & 0.017 & 0.002 & 0 & 0.136 & 0.078 & 0.048 & 0.454 & 0.044 & 0 \\
\hline 23 & 0.036 & 0.005 & 0 & 0.292 & 0.168 & 0.103 & 0.972 & 0.094 & 0 \\
\hline 24 & 0.061 & 0.009 & 0 & 0.503 & 0.289 & 0.177 & 1.674 & 0.163 & 0 \\
\hline 25 & 0.092 & 0.013 & 0 & 0.167 & 0.012 & 0.104 & 0.016 & 0.002 & 0 \\
\hline 26 & 5.290 & 0 & 0 & 51.118 & 0 & 0.068 & 0.134 & 0 & 0 \\
\hline 27 & 0.233 & 0 & 0 & 0.006 & 0 & 0.088 & 0.683 & 0.092 & 0 \\
\hline 28 & 0 & 0 & 0 & 0 & 0 & 0.023 & 0.051 & 0 & 0 \\
\hline 29 & 0 & 0 & 0 & 0.111 & 0.594 & 1.946 & 7.201 & 0 & 0.192 \\
\hline 30 & 0.789 & 0.043 & 0 & 0.374 & 0.331 & 9.764 & 0.779 & 0.028 & 0 \\
\hline 31 & 0.923 & 0.050 & 0 & 1.043 & 0.366 & 11.228 & 0.810 & 0.030 & 0 \\
\hline 32 & 0.033 & 0.002 & 0 & 0.934 & 0.355 & 0.704 & 0.159 & 0.541 & 0 \\
\hline 33 & 0.009 & 0 & 0 & 0.194 & 0 & 1.083 & 2.199 & 0.318 & 3.579 \\
\hline 34 & 0.013 & 0 & 0 & 0.295 & 0 & 1.647 & 3.345 & 0.484 & 5.443 \\
\hline 35 & 0.056 & 0 & 0 & 1.274 & 0 & 7.126 & 14.473 & 2.092 & 23.551 \\
\hline 36 & 0 & 0 & 0 & 0.038 & 0.018 & 0.827 & 0.562 & 0 & 0 \\
\hline 37 & 0.008 & 0 & 0 & 0.056 & 0 & 0.150 & 0 & 0.045 & 0 \\
\hline 38 & 0.008 & 0 & 0 & 0.058 & 0 & 0.153 & 0 & 0.046 & 0 \\
\hline 39 & 0 & 0 & 0 & 0.002 & 0 & 0.006 & 0 & 0.002 & 0 \\
\hline 40 & 0.020 & 0.001 & 0 & 0.146 & 0 & 0.388 & 0 & 0.117 & 0 \\
\hline 41 & 0.056 & 0.003 & 0 & 0.415 & 0 & 1.104 & 0 & 0.333 & 0 \\
\hline 42 & 0.002 & 0 & 0 & 0.012 & 0 & 0.032 & 0 & 0.010 & 0 \\
\hline 43 & 0.010 & 0.001 & 0 & 0.074 & 0 & 0.198 & 0 & 0.060 & 0 \\
\hline 44 & 0.530 & 0.029 & 0 & 0.299 & 0 & 0.643 & 1.902 & 2.194 & 1.918 \\
\hline 45 & 0.034 & 0.002 & 0 & 0.332 & 0 & 0.921 & 0.425 & 0.014 & 0 \\
\hline 46 & 1.240 & 0.067 & 0 & 0.518 & 0 & 0 & 0 & 0.144 & 0 \\
\hline 47 & 3.156 & 0.170 & 0 & 0.976 & 0 & 0.835 & 0 & 0 & 0 \\
\hline 48 & 0.051 & 0.003 & 0 & 0.036 & 0 & 0.636 & 0 & 0.056 & 0 \\
\hline 49 & 0.029 & 0.002 & 0 & 0.020 & 0 & 0.359 & 0 & 0.032 & 0 \\
\hline
\end{tabular}




\section{References}

Baines, J. T. (1993) New Zealand Energy Information Handbook. Christchurch: Baines and Associates.

Cornwell, A. and Creedy, J. (1997) Environmental Taxes and Economic Welfare:

Reducing Carbon Dioxide Emissions. Cheltenham: Edward Elgar.

Creedy, J. and Sleeman, C. (2004) Carbon Taxation, Prices and Welfare in New Zealand. New Zealand Treasury Working Paper 04/25.

Dorfman, R., Samuelson, P. and Solow, R. (1958) Linear Programming and Economic Analysis. New York: McGraw-Hill.

Ministry of Economic Development (2003) New Zealand Energy Greenhouse Gas Emissions 1990-2002. Wellington: MED.

http://www.med.govt.nz/ers/en_stats/green2002/contents.html

Proops, J. L. R., Faber, .M. and Wagenhals, G. (1993) Reducing CO2 Emissions: A Comparative Input-Output Study for Germany and the UK. Heidelberg: Springer-Verlag.

Statistics New Zealand (2004) New Zealand Energy Flow Account. Wellington: Statistics New Zealand. 